\title{
Dlaczego Zachód wymiera? Oświeceniowe źródła trendów antypopulacyjnych. Wzorce konsumpcji, samorealizacji i zbawienia w doczesności
}

Kamień węgielny naszego współczesnego sposobu życia został położony na przełomie XVII i XVIII wieku. Oświeceniowy projekt przebudowy kultury europejskiej zniósł dotychczasowy, chrześcijański wymiar cywilizacji łacińskiej. „Całość ludzkiego doświadczenia miała tylko potwierdzić werdykt rozumu głoszący, że filozofia chrześcijańska wspierana przez nietolerancję, przesąd i tyranię była główną przeszkodą na drodze do szczęścia ludzkości”" Nowa treść zbiorowego światopoglądu została przyjęta, gdy cywilizacja łacińska urzeczywistniła już pełnię swoich możliwości i zaczęła tracić swą ożywczą moc. Oświecenie było końcem społeczeństwa tradycyjnego z silną rolą religii i szlachty w życiu społecznym. Proces przemian społeczno-kulturowych zapoczątkowanych renesansem i reformacją doprowadził do odrzucenia wymiaru sacrum opartego na transcendencji i przyjęcia w życiu społecznym kryterium racjonalistycznego pragmatyzmu. Przewodnia rola w świecie kultury i obyczajowości przeszła $\mathrm{w}$ ręce nowej szlachty i burżuazji. Wśród popularyzowanych przez nowe elity postaw dominowały indywidualizm i utylitaryzm. Ideał

Doktor, Akademia Humanistyczno-Ekonomiczna w Łodzi.

C. Becker, Państwo Boże osiemnastowiecznych filozofów, Poznań 1995, s. 79. 
rycerza-arystokraty został zastąpiony przez wzorzec merkantylnie myślącego przedsiębiorcy ${ }^{2}$.

Dominujące we współczesnym świecie wzorce konsumpcji i samorealizacji są bezpośrednią konsekwencją zaproponowanej przez filozofów oświecenia wizji człowieka. Był to model opierający się na zupełnie innych przesłankach niż antropologia starożytna czy chrześcijańska. Cywilizacja helleńska stawiała na osiąganie pełni człowieczeństwa - duchowej, intelektualnej i fizycznej doskonałości - poprzez paideję: wychowywanie i doskonalenie jednostki jako aktywnego członka wspólnoty politycznej. W cywilizacji łacińskiej miarą wielkości było wzniesienie się ponad człowieczeństwo poprzez podążanie drogą krzyża: świętości i zbawienia. Chrześcijaństwo sytuowało człowieka jako istotę będącą Bożym dzieckiem przebóstwionym przez ofiarę Chrystusa, poddaną Bożej władzy i opiece. Czyniło człowieka podmiotem i celem, a nie środkiem czy przedmiotem jakiegokolwiek innego celu czy działania ${ }^{3}$. Chrześcijaństwo zbudowało antropologię, „która z istoty ludzkiej czyni o s o b ę, obdarzając ją świętą, nienaruszalną wartością. Kultura europejska jest historią epifanii osoby, która w czasach nowożytnych rozwinęła się w autonomiczny podmiot, zdolny do własnego projektu i niezależności duchowej”"

Rozwijane w nowożytności badania naukowe w dziedzinie medycyny i biologii doprowadziły do odarcia człowieka z tej wyjątkowości, sprowadzając go do królestwa zwierząt, a następnie maszyn. Julien Offray de La Mettrie pytał:

czym był człowiek przed wynalezieniem wyrazów i umiejętności mowy? Zwierzęciem w swoim rodzaju, posiadającym znacznie mniej instynktu przyrodzonego od innych, a nie uważającym się wówczas za pana stworzenia. Zwierzę to odznaczało się z pośród małp i innych zwierząt tymi cechami, które różnią małpę od dzisiejszego człowieka, mianowicie rysami twarzy znamionującymi większą roztropnośćs.

Przyrodoznawcy nie znaleźli podstaw ani uzasadnień dla godności czy wyjątkowości człowieka. Stąd postulat: „[...] weźmy do pomocy anatomię porównawczą; odkryjmy wnętrzności człowieka i zwierząt. W taki tylko sposób możemy poznać naturę ludzką [...]"',

[...] człowiek jest tylko zwierzęciem lub mechanizmem, złożonym z nakręcających się wzajemnie sprężyn, tak iż niepodobna orzec, w którym punkcie koła ludzkiego

2 P. Hazard, Kryzys świadomości europejskiej 1680-1715, Warszawa 1974, s. 290.

3 „Jeżeli godność jest tymczasowa, zmienna zależnie od okresu życia, jeżeli może znikać albo pojawiać się na nowo, to ile jest naprawdę warta?". Cyt. za: C. Delsol, Esej o człowieku późnej nowoczesności, Kraków 2003, s. 29.

4 Ibidem, s. 13.

5 J. La Mettrie, Człowiek-maszyna, Warszawa 2003, s. 43.

6 Ibidem, s. 35. 
rozpoczęła natura swą działalność. Sprężyny te różnią się między sobą tylko co do ich położenia i pewnego ustopniowania ich siły, nie zaś co do istoty. Dusza jest zatem tylko pierwiastkiem poruszającym, czyli wrażliwą częścią materialną mózgu, którą można bez obawy popełnienia błędu rozpatrywać jako główną sprężynę całej maszyny. Wywiera ona wpływ widoczny na pozostałe sprężyny i nawet, jak się wydaje, została najpierw utworzona, tak iż tamte wszystkie były tylko jej emanacjami ${ }^{7}$.

Konsekwencjami nowej antropologii były nurty kultury, które wolelibyśmy postrzegać jako wynaturzenia i pomyłki racjonalistycznej filozofii. Alternatywą dla uniwersalistycznej antropologii chrześcijańskiej okazał się podział gatunku ludzkiego na grupy, które zasługują na szacunek z racji swych przymiotów, oraz wykluczonych i dyskryminowanych (niepełnosprawnych, Żydów, Cyganów, Słowian, homoseksualistów). Istotną zależność pokazuje Chantal Delsol, pisząc o paradoksach późnej nowoczesności: „Jeżeli postęp nauki wystarczył do naruszenia przekonania o wyjątkowości rodzaju ludzkiego, stało się tak dlatego, że samej nauce powierzono poszukiwanie kryteriów i definicji, przekazy religijne uznając za nieprawomocne"8. Współczesnej wizji człowieka brakuje uzasadnień dla skutecznej ochrony godności każdego człowieka przed nieludzkim, nieosobowym traktowaniem (również w wersji soft, czyli manipulowania opinią publiczną czy kreowania potrzeb konsumenckich przez marketing i modę). Ufundowana na humanizmie wizja człowieka okazała się równie nieskuteczna jak jej chrześcijańska poprzedniczka. Tortury, karę śmierci, nierówność prawa dla kobiet i niższych warstw społecznych zastąpiły akceptacja aborcji, polityki publiczne prowadzone na zasadzie inżynierii społecznej, eksperymenty medyczne igrające $z$ procesami modyfikacji genetycznych i doboru pożądanych cech przy sztucznym zapłodnieniu.

Na rudymentarne znaczenie wizji człowieka w przemianach dokonanych przez filozofów oświecenia zwracał uwagę José Ortega y Gasset:

Błędy, które popełnił człowiek czystego intelektu są rozliczne, ale dadzą się w formie najbardziej ogólnej sprowadzić do dwóch niewłaściwie pojętych założeń. Pierwsze dotyczy błędnej filozofii człowieka, drugie błędnej filozofii kultury9

Ortega wskazywał na dwa najważniejsze błędy oświeceniowej antropologii - przekonanie o wszechmocy człowieka oraz o nieomylności rozumu we wszystkich sferach ${ }^{10}$. Przekonania te stały się podstawą dla wytworzenia się grupy społecznej intelektualistów, którzy przypisują sobie prawo do stwarzania społeczeństwa na nowo, korzystania z narzędzi inżynierii społecznej (głównie

\footnotetext{
Ibidem, s. 90.

8 Ch. Delsol, op. cit., s. 19.

9 K. Polit, Kryzys cywilizacji Zachodu w myśli José Ortegi y Gasseta, Lublin 2005, s. 126.

10 Ibidem, s. 159.
} 
pozytywnego prawodawstwa), aby kształtować państwo, społeczeństwo i człowieka na obraz własnych koncepcji.

Antropologia humanistyczna doprowadziła do przyznania absolutnej władzy rządzącym zamiast zabezpieczać rozproszoną władzę wolnych jednostek i wspólnot. Zdaniem Giovanniego Pico della Mirandoli, wyjątkowość człowieka polega na tym, że „może on sam siebie uformować w kształt dowolnego ciała, przybrać naturę każdego stworzenia, stwarzać się i przekształcać" ${ }^{11}$. Konsekwencje, jakie płyną z takiego postawienia rzeczy, czynią człowieka nie tylko panem wszelkiego stworzenia, lecz również wszelkim stworzeniem ${ }^{12}$, rozumianym jednak nie na sposób biblijny, jako możliwości dokonywania wysiłku nad kształtowaniem własnego charakteru, lecz na sposób nowożytny, jako pole dla manipulacji inżynierów społecznych. Człowiek jest samodzielnym twórcą własnej tożsamości i wszystkiego, co określa jego byt jednostkowy i społeczny. Późniejsi myśliciele wyciągnęli dalej idące wnioski, twierdząc, że ci, którzy zaszli dalej na drodze ćwiczeń rozumu i woli, mogą dowolnie kształtować inne, mniej rozumne osoby. Wielkie eksperymenty oświecenia publicznego, ale przede wszystkim projekty stworzenia "nadczłowieka” i homo sovieticusa pokazały, jak wielkim zagrożeniem może być takie postrzeganie człowieka.

Droga, jaka miała doprowadzić do wytworzenia się nowego człowieczeństwa, wymagała ograniczenia wolności i podmiotowości osoby ludzkiej.

Wraz z Rousseau myślenie o człowieku jako istocie politycznej, o powstaniu społeczeństwa, o państwie i prawie „wykonało istny skok kwantowy” o ogromnych konsekwencjach. O ile wysiłki oświecenia szły w tamtym czasie - stanowiąc pogłos arystotelesowskiej i, przede wszystkim, chrześcijańskiej koncepcji wyjątkowości i jedyności osoby ludzkiej - w kierunku uwolnienia jednostki z kolektywnych przymusów, o tyle dla Rousseau było to „grzechem pierworodnym” ludzkości. [...] Dopiero, kiedy jednostka „rozpuści” swoją odrębność w wielkim ciele o nazwie „lud”, stanie się - wedle wyobrażenia Rousseau - posłuszną częścią w procesie realizowania volonté générale (woli powszechnej, woli ludu) ${ }^{13}$.

Rousseau dążył do pozbawienia ludzi własności prywatnej, nie tylko majątku, lecz również ich odrębności i prywatności. Przymus polityczno-prawny miał posłużyć jednolitemu kierownictwu wszystkimi sprawami obywateli, zgodnie $\mathrm{z}$ wolą prawodawcy.

Ażeby wykryć najlepsze, korzystne dla narodów reguły społeczne, potrzeba umysłu wyższego, któryby widział wszystkie namiętności ludzkie, a sam nie doznawał żadnej;

11 Ibidem, s. 45.

12 Num. 27, 16-17, Mk. 16, 15.

13 R. Baader, Śmiercionośne myśli. Dlaczego intelektualiści niszczą nasz świat, Wrocław 2009, s. 179-180. 
któryby był pozbawiony wszelkiego stosunku z naszą naturą, a znał ją gruntownie; którego szczęście byłoby od nas niezależne, a który jednak chciałby się naszem szczęściem zająć; któryby wreszcie, zachowując sobie w postępie dziejów sławę odległą, mógł pracować w pewnym wieku, zbierać plony w drugim ${ }^{14}$.

[Prawodawca] miał [...] być nie reformatorem ustroju, a jego twórcą, tworzącym z niczego. Dawne instytucje miał przekreślić lub nadać im inny sens. Tworzyć zaś miał nie tylko prawa, ale i obyczaje, a nawet samą psychikę narodu, gdyż jako rzecz pewną zakładał Rousseau, że różnice charakterów narodowych zależą od systemów prawnych ${ }^{15}$.

Nie mam wątpliwości, że obywatel Genewy myślał o sobie samym, pisząc, że „trzeba by bogów, ażeby nadać ustawy ludziom”16. Kilka akapitów dalej uczynił z prawodawcy człowieka z krwi i kości, przydając mu nadzwyczajne miejsce w państwie. Sugerował, że, jak Likurg prawodawca, powinien zrzec się władzy, zauważając z satysfakcją, że „było zwyczajem większości miast greckich powierzać cudzoziemcom urządzenie i własnych. Nowożytne republiki włoskie naśladowały nieraz ten obyczaj; republika genewska uczyniła to samo i wyszła na tem dobrze"17. W ten sposób Rousseau uzasadniał napisanie projektów ustroju politycznego dla Polski i Korsyki, choć stokroć bardziej pragnąłby występować jako prawodawca Francji.

Philosophes postrzegali społeczeństwo jako mechanizm podlegający dowolnym modyfikacjom, ulepszeniom, a nawet całościowej kreacji. Sformułowane przez Karola Marksa „aktywistyczne hasło: „Filozofowie rozmaicie tylko interpretowali świat; idzie jednak o to, aby go zmienić" "18 znakomicie oddaje orientację inżynierów społecznych. Ich główną ambicją pozostaje zmodyfikowanie tożsamości człowieka, ona jest warunkiem i wstępem do skutecznej przebudowy społeczeństwa: „Z punktu widzenia politycznego podstawowy problem polega więc na ukształtowaniu pobudek działania ludzi w taki sposób, aby energia ich kierowała się na właściwe punkty strategiczne, a cały proces rozwoju odbywał się w pożądanym kierunku"19. William Galson, politolog i były doradca prezydenta Clintona do spraw polityki wewnętrznej, zauważył: »Prawo jest w stanie zmieniać motywacje, a motywacje są w stanie kształtować zachowanie. [...]«"20.

Apologetą planowego kształtowania tożsamości człowieka był Jean-Jacques Rousseau, pisząc: „ten, kto podejmuje się organizowania ludu, powinien czuć

14 J.-J. Rousseau, Umowa społeczna, czyli zasady prawa politycznego, Poznań 1920, s. 40.

15 Z. Szpotański, O wolności myślenia, Kraków 1986, s. 87.

16 J.-J. Rousseau, op. cit., s. 40.

17 Ibidem, s. 41-42.

18 K. Popper, Nędza historycyzmu, Warszawa 1999, s. 58.

19 K. Mannheim, Człowiek i społeczeństwo w dobie przebudowy, Warszawa 1974, s. 291.

20 G. Himmelfarb, Jeden naród, dwie kultury, Warszawa 2007, s. 80. 
się na siłach zmienić, że tak powiem, naturę ludzką; przekształcić każdą jednostkę..." ${ }^{\prime 2}$. Nie był to pozbawiony konsekwencji wybryk intelektualny tamtych czasów. W XX wieku w podobnym tonie wtórował mu m.in. członek Klubu Rzymskiego, Georg Picht, który pisał: „hodując przyszłego człowieka winniśmy zdobyć się na tyle samo przynajmniej troskliwości i zróżnicowania metod, ile w hodowli roślin lub zwierząt uważamy za oczywistość”22. Idee polityczne oraz aspiracje oświeceniowych myślicieli padły na niezwykle podatny grunt, wydając owoce $\mathrm{w}$ postaci aktywistycznie nastawionych ideologii, urzeczywistniających ideały powszechnej równości, indywidualistycznej wolności, ekonomizacji polityki i życia wspólnotowego na żywej tkance europejskich społeczeństw. Dlatego - jak stwierdza Picht - „[...] nie należy już pytać, do kogo należy wydawanie praw, skoro są one aktami woli powszechnej; ani też, czy władca stoi ponad prawem, skoro jest członkiem państwa; ani czy prawo może być niesprawiedliwe, skoro nikt nie jest niesprawiedliwy wobec samego siebie"23.

Potrzebowano odmiennego systemu etycznego, który miał wspierać kształtowanie człowieka podług nowego wzorca.

Podstawowe artykuły religii oświecenia można sformułować następująco: 1) człowiek nie jest zły z przyrodzenia; 2) celem życia jest samo życie, dobre życie na ziemi zamiast uszczęśliwiającego życia po śmierci; 3) człowiek jest zdolny, biorąc za przewodnika wyłącznie światło rozumu i doświadczenie do doskonalenia swojego życia na ziemi; 4) pierwszym i podstawowym warunkiem dobrego życia na ziemi jest uwolnienie umysłów z więzów ignorancji i przesądów, a ciał z ucisku samowolnej władzy ${ }^{24}$.

Uwolnieniu człowieka od zewnętrznego osądu objawionych przykazań służyła etyka Rousseau. „Na swoje własne konto Rousseau rozwija w nich [w Dialogach - przyp. autora] ciekawą doktrynę bezwzględnego NIESPRZECIWIANIA się impulsom Uczucia, doktrynę całkowitej bierności, jako warunku pierwotnej Dobroci, która jest kwietyzmem natury"25. Filozof postawił człowieka naturalnego, dobrego, prymitywnego ponad człowiekiem cnotliwym, wszak cnota jest jedynie przesądem zepsutego społeczeństwa, więc nie znajduje zastosowania w doskonałym świecie natury. Rousseau do najprostszych, pierwotnych czynności człowieka, wcześniejszych jeszcze od rozumu zaliczał troskę o własną pomyślność i życie oraz wstręt do cierpienia i śmierci drugiego człowieka ${ }^{26}$. Uważał, że tylko bazując na przyrodzonych popędach i instynktach, jednostki

21 J.-J. Rousseau, op. cit., s. 41.

22 G. Picht, Odwaga utopii, Warszawa 1981, s. 91.

23 Ibidem, s. 69.

24 C. Becker, op. cit., s. 75.

25 J. Maritain, Trzej reformatorzy, Warszawa-Ząbki 2005, s. 158.

26 J.-J. Rousseau, Trzy rozprawy z filozofii społecznej, Warszawa 1956, s. 133. 
są w stanie wpisać się w ideał dobrego życia we wspólnocie zorganizowanej i zarządzanej przez oświeconego prawodawcę.

Racjonalność instrumentalna, która stała się głównym kryterium oceny działań sprowadzała się w praktyce do rachunku ekonomicznego ${ }^{27}$. Ograniczenie horyzontu myślowego do indywidualnego interesu jednostki wiązało się z odrzuceniem heroicznego wymiaru życia. W konsekwencji utraciliśmy wiarę w symbole, które mogły nadawać wyższy sens naszemu życiu. Jak zauważa Nikołaj Bierdiajew, „renesans zaczął się od afirmacji indywidualności twórczej człowieka, skończył się natomiast na jej negacji. Człowiek bez Boga przestaje być człowiekiem [...]"28. Współczesne dzieła kultury bywają grą, zabawą, najczęściej jednak są wyrazem sprzeciwu, gdyż nie ma już podstaw do pozytywnej twórczości. Stan sztuki jest symboliczną diagnozą stanu współczesnego społeczeństwa, opartego na negacji aksjologii wykraczającej poza praktyczny wymiar mierzalnych i racjonalnych korzyści.

$\mathrm{W}$ oświeceniowych nurtach ideowych można doszukiwać się również wątków gnostyckich, które w historii ludzkości pojawiały się niejednokrotnie bez oczywistej przyczyny. Tendencje gnostyczne mają swoje źródło w doświadczeniu i niezgodzie na cierpienia doświadczane w codziennym życiu. Bunt, jaki wywołuje zło tego świata, prowadzi do odrzucenia niedoskonałości świata na rzecz poszukiwania zbawienia $\mathrm{w}$ doczesności poprzez przekroczenie ograniczeń człowieczeństwa. Istnieją dwie drogi owego wykroczenia poza nasze ograniczenia: duchowa realizowana przez romantyzm i New Age oraz racjonalna, odbywająca się dzięki wysiłkowi rozumu, który odkryje przestrzenie witalności niedostępne przeciętnemu człowiekowi. Karl Popper tę przemożną ideę, będącą celem oświeceniowego dzieła Immanuela Kanta („do wejścia na drogę oświecenia nie potrzeba niczego prócz wolności i to wolności najnieszkodliwszej spośród wszystkiego, co nazwać można wolnością, mianowicie wolności czynienia wszechstronnego, publicznego użytku ze swego rozumu"29), nazywa samowyzwoleniem przez wiedzę ${ }^{30}$. Oba nurty oświecenia, racjonalny i romantyczny, obiecywały stworzenie nowego ideału świata: racjonalistycznego bądź duchowego. Strukturę ramową tego ideału wyznaczało państwo lub wspólnota, w której rozpłynąć się miała indywidualna egzystencja poszczególnych jednostek ${ }^{31}$. Wołanie ludzi o zbawienie „może teraz - gdy już Bóg nie jest

27 Ch. Taylor, Etyka autentyczności, Kraków 2002, s. 10-12.

28 N. Bierdiajew, Nowe Średniowiecze. Los człowieka we współczesnym świecie, Warszawa 2003, s. 42.

29 I. Kant, Co to jest Oświecenie, [w:] Z. Libera, Oświecenie, Warszawa 1974, s. 230.

30 K. Popper, W poszukiwaniu lepszego świata. Wykłady i rozprawy z trzydziestu lat, Warszawa 1997, s. 161.

31 M. Brumlik, Gnostycy. Marzenie o samozbawieniu człowieka, Gdynia 1999, s. 227. 
umiejscowiony ani w niebie, ani u początku dziejów - kierować się na dowolną rzecz: na własną psyche, na intymne współżycie ludzi, albo na kształtowanie stosunków społecznych, ekonomicznych czy politycznych"32. Poszczególne nurty intelektualne czasów nowożytnych są taką właśnie próbą realizacji, upostaciowienia przemożnego pragnienia zbawienia człowieka w życiu doczesnym. Ideologie polityczne, systemy naukowe, koncepcje psychologiczne usiłują zastąpić chrześcijaństwo w dostarczaniu takiej nadziei. Idea samozbawienia człowieka popychała ludzi do zaangażowania w wielkie projekty polityczne, jednak w ostatnich czasach daje się zaobserwować przesunięcie w stronę aspektów ekonomicznych: zbawczych wymiarów samorealizacji zawodowej i konsumpcji, jako wzorców „dobrego życia”.

Współczesny człowiek „poszukuje najbardziej ekonomicznych form, by osiągnąć cele osobiste i cały czas ewoluuje w kierunku narcyzmu skłonny mniemać, że samorealizacja to cel najwyższy. Jest bardzo podatny na mit "pełni życia « kultywowany przez kulturę masową [...]"33. Wiara, że dzięki podążaniu drogą rozwoju kariery, indywidualnej samorealizacji osiągniemy życiowy sukces, w praktyce okazuje się być daleko idącym złudzeniem. Osoby pracujące o wysokich dochodach, zamiast awansować w hierarchii klas społecznych, uczestniczą w wyścigu konsumpcyjnym. Zachęcanie ludzi do wyróżniania się z tłumu prowadzi do nieustannego wzrostu postaw konsumpcyjnych. Ludzie zamiast zaspokajać potrzeby podstawowe, a nadwyżki inwestować w kapitał rentierski i zabezpieczenie, starają się uzyskać wyższy status społeczny poprzez nabywanie dóbr zapewniających wyróżnienie się z tłumu.

Musimy więc zrozumieć, jaka siła moralna tkwi w takich pojęciach jak samorealizacja. Kiedy bowiem uznamy je po prostu za rodzaj egoizmu, przejaw moralnej słabości, folgowanie sobie w porównaniu do wymogów - surowszych i wyższych - dawnych czasów, to zgubimy właściwy trop. Retoryka "permisywizmu « nie trafia w sedno. Moralnej słabości nam nie brakuje, lecz nasza epoka nie jest pod tym względem wyjątkowa. Nam zależy na wyjaśnieniu tego, co swoiste dla współczesności. Nie chodzi więc po prostu o to, że ludzie rezygnują z trwałych związków i przestają się zajmować swoimi dziećmi, żeby poświęcić się karierze zawodowej. Takie zjawisko istniało zapewne zawsze. Rzecz w tym, że dzisiaj wielu odczuwa takie powołanie: czują, że powinni tak uczynić, że ich życie byłoby w jakimś sensie stracone czy niespełnione, gdyby postąpili inaczej ${ }^{34}$.

Wyniesiony od Rousseau bezwzględny nakaz niesprzeciwiania się uczuciom wyrugował odpowiedzialność za własne dzieci i trwałość związku

32 Ibidem, s. 223.

33 A. Sepkowski, Źródła populizmu w wyobrażeniach zbiorowych, [w:] Populizm na przełomie XX i XXI wieku. Panaceum czy pułapka dla współczesnych społeczeństw?, M. Marczewska-Rytko (red.), Toruń 2006, s. 108-109.

34 C. Taylor, op. cit., s. 23. 
małżeńskiego. $\mathrm{W}$ przekazie kultury popularnej dorosłość utożsamioną $\mathrm{z}$ odpowiedzialnością przeciwstawiono wiecznemu dzieciństwu, w którym nic nie krępuje swobodnego zaspokajania własnych pragnień. Dorosłość nie musi jednak oznaczać zaprzedania swoich ideałów, odpowiedzialność nie stanowi alternatywy wobec wolności.

Współczesna kultura oparła się na egoizmie wyniesionym do poziomu wzorca społecznego. Przeżywane indywidualnie szczęście znajduje się w kontrze wobec postawy poświęcenia się, służby drugiemu człowiekowi. Dlatego jedynym powodem dla posiadania potomstwa jest kolejny etap zaspokajania własnych potrzeb. Rodzicielstwo stanowi swoiste uzupełnienie katalogu posiadanych rzeczy. Wychowywanie dziecka staje się taką samą oznaką statusu i społecznego prestiżu jak hodowanie rasowego pieska czy odrestaurowanie zabytkowego samochodu. Przesunięcie ciężaru życiowej aktywności na sprawy materialne odbywa się kosztem relacji rodzinnych i społecznych.

Tradycyjny model rodziny podlegał $\mathrm{w}$ postoświeceniowym świecie systematycznej erozji. W Stanach Zjednoczonych już w latach 1870-1920 liczba rozwodów wzrosła piętnastokrotnie. W 1924 roku co siódme małżeństwo kończyło się rozwodem, podczas gdy obecnie rozpada się co drugie ${ }^{35}$. Joseph Schumpeter wzrost liczby rozwodów tłumaczył rozprzestrzenieniem się racjonalistycznego rachunku kosztów i zysków na sferę życia prywatnego ${ }^{36}$. W sytuacji, gdy z punktu widzenia jednego z małżonków mógłby on uzyskiwać większe korzyści poza małżeństwem, nic nie stało na przeszkodzie dla podjęcia decyzji o porzuceniu rodziny i realizowaniu indywidualnego szczęścia.

Kiedy mężczyźni opuszczają swoje rodziny, ich realny poziom życia wzrasta o 73 procent - chociaż poziom życia pozostawionej rodziny spada o 42 procent. [...] Gdzie jednak mają się zrodzić naciski na rzecz wartości społecznych wspierających ofiary, jakie trzeba ponieść dla utrzymania rodziny? Obecne wartości opowiadają się raczej za wyborem niż za więzami ${ }^{37}$.

W obronie skrajnego egoizmu osób nieposiadających dzieci powstał nawet w Stanach Zjednoczonych ruch childfrees, którego manifestem jest książka Elinor Burkett Korzyści z dziecka, czyli jak prorodzinna Ameryka okrada bezdzietnych. Brak wierności małżonkowi i własnej przysiędze jemu złożonej na Zachodzie przestał być aktem społecznie piętnowanym. Przeszliśmy od dożywotniej monogamii w stronę kilkukrotnej monogamii krótkotrwałej

35 G. Himmelfarb, op. cit., s. 64.

36 J.A. Schumpeter, Kapitalizm, socjalizm i demokracja, Warszawa 1995, s. 194-195.

37 L. Thurow, Przyszłość kapitalizmu. Jak dzisiejsze siły ekonomiczne kształtują świat jutra, Wrocław 1999, s. 53. 
oraz związków patchworkowych - wychowywania dzieci z różnych związków z obecnym i poprzednimi partnerami.

Konsekwencją odejścia od tradycyjnych instytucji i ról społecznych jest wyraźny kryzys demograficzny świata zachodniego. „O strukturalnym charakterze tego zjawiska świadczy głęboki i względnie trwały spadek płodności, znacznie poniżej minimalnego poziomu umożliwiającego prostą reprodukcję populacji”38. W XX wieku dokonało się na Zachodzie przejście od reprodukcji rozrzutnej (wiele dzieci, ogromna umieralność noworodków, średnia życia około 30 lat) do reprodukcji oszczędnej (nieliczne potomstwo, bardzo wysoka przeżywalność dzieci, średnia wieku 70 lat, starcy w dobrym zdrowiu) ${ }^{39}$. Potencjał ludnościowy Zachodu uległ drastycznemu zmniejszeniu w stosunku do pozostałych cywilizacji. O ile w 1950 roku populacja cywilizacji niezachodnich stanowiła 68\% całości ludzkości, w roku 2000 już 80\%, a w ciągu najbliższego półwiecza może zbliżyć się do $90 \%{ }^{40}$. Spadek dzietności na Zachodzie demografowie nazywają drugim przejściem demograficznym. Polega ono na rozpadzie „rodziny jako instytucji, której jeden z nadrzędnych celów stanowi prokreacja i transmisja pokoleń" ${ }^{41}$.

Kapitalistyczny system pracy nastawiony na wysoką wydajność i realizowanie wymagającej poświęceń ścieżki kariery, uzupełniony modelem konsumpcjonizmu, wyparł spośród listy priorytetów życiowych posiadanie potomstwa. „Przedsiębiorstwo kapitalistyczne - w czym możemy zgodzić się z Marksem - odgrywało niezwykle istotną rolę w odrywaniu nowoczesnego życia społecznego od instytucji tradycyjnego świata"42. Utowarowieniu uległy zarówno siła robocza, jak i w dalszej kolejności potrzeby i wartości społeczności, w tym merkantylizowana decyzja o posiadaniu potomstwa. Państwowe systemy zabezpieczenia socjalnego, zdrowotnego i emerytalnego wyeliminowały ostatnie motywacje ekonomiczne do posiadania dzieci. Jednocześnie perspektywa temporalna skróciła się do teraźniejszości do tego stopnia, że dla wielu przedstawicieli Zachodu niczym niepokojącym nie byłby fakt, gdyby ich pokolenie było ostatnim na Ziemi.

Gdyby stan antykultury, cywilizacji śmierci, miał potrwać dłużej, to w perspektywie najbliższego stulecia społeczeństwom Europy Zachodniej istotnie grozi wymarcie. Imigranci z islamskiego kręgu kulturowego zamieszkują w europejskich miastach, ale nie przejmują kulturowej schedy po tych, którzy je

\footnotetext{
38 M. Okólski, Cywilizacje przypływu, cywilizacja odplywu demograficznego, [w:] Wiek wielkich przemian, M. Dobroczyński, A. Jasińska (red.), Warszawa-Toruń 2001, s. 15.

39 Ibidem, s. 13.

40 Ibidem, s. 15.

${ }^{41}$ Ibidem, s. 16.

42 A. Giddens, Konsekwencje nowoczesności, Kraków 2008, s. 45.
} 
wybudowali. Narody europejskie zaś, tak jak myszy z eksperymentu „mysiej utopii” Johna Calhouna, przestały się rozmnażać nawet na poziomie odtwarzalności pokoleń. Eksperyment Calhouna z 1968 roku polegał na stworzeniu doskonałego środowiska życia: otoczenia zdolnego pomieścić 3840 myszy, bez drapieżników, z dostatkiem pożywienia, picia i materiałów do budowy gniazd, opieką weterynaryjną, przyjazną temperaturą. W ciągu trwającego cztery lata eksperymentu (wielokrotnie później, z tym samym skutkiem powtarzanego) populacja stworzona z początkowej grupy ośmiu myszy osiągnęła maksymalną liczebność 2200 osobników, po czym zaczęła się degenerować (zanik instynktu macierzyńskiego, wycofanie $\mathrm{z}$ relacji społecznych ${ }^{43}$, samce przestały zabiegać o samice, część samców okazywało agresję wobec innych, dochodziło do aktów homoseksualnych) i ostatecznie wymarła. Do ostatniego urodzenia doszło w 920 dniu eksperymentu.

Zdaniem Calhouna do zaniku relacji społecznych doprowadziło usunięcie $\mathrm{z}$ otoczenia badanej populacji śmiertelnych zagrożeń. Sztuczne wyeliminowanie zagrożenia głodu, wychłodzenia i ataku drapieżników umożliwiło przetrwanie bez współpracy z innymi osobnikami. W konsekwencji zaniku interakcji, zaburzeniu uległy role społeczne, które stanowiły infrastrukturę dla interakcji seksualnych. Organizacja społeczna myszy rozpadła się, bo dla młodego pokolenia zabrakło ról społecznych, które mogłyby pełnić. W zamkniętej społeczności, od której nie można było się odłączyć, istniała ograniczona pula pozycji dla samców. Walki młodych osobników ze starszym pokoleniem były tak zaciekłe, że prowadziły do zniszczenia ładu społecznego. W konsekwencji, pozbawione poczucia bezpieczeństwa matki zaczęły odrzucać swoje młode. Stłoczenie na małej, zamkniętej przestrzeni społeczności rozrywanej konfliktami wymusiło skrócenie i uproszczenie relacji społecznych, a w konsekwencji przyniosło nieumiejętność budowania złożonych relacji niezbędnych do wychowywania młodych. „Dla zwierzęcia tak prostego jak mysz, większość złożonych zachowań wiąże się z zalotami, opieką macierzyńską, obroną terytorium i hierarchiczną wewnątrz- i międzygrupową organizacją. Gdy zachowania odnoszące się do tych funkcji nie rozwiną się, zanika organizacja społeczna i reprodukcja" ${ }^{44}$. Ostatecznie nawet myszy przeniesione w końcowej fazie eksperymentu do innej populacji nie zaczęły wchodzić w interakcje seksualne, pozostały tak samo bierne pomimo zmienionych warunków.

43 Prawdopodobną przyczyną wycofywania się samców z męskich ról społecznych była niemożność emigracji lub ekspansji na nowe terytoria tych samców, które przegrały rywalizację wewnątrz mysiej populacji.

44 J. Calhoun, Death Squared: The Explosive Growth and Demise of a Mouse Population, http://www.ncbi.nlm.nih.gov/pmc/articles/PMC1644264/pdf/procrsmed00338-0007. pdf [dostęp: 26.04.2016]. 
Zmniejszenie się dzietności w zachodnich społeczeństwach wynika najprawdopodobniej z zaburzenia kobiecych i męskich wzorców i ról społecznych. Trendom kulturowym towarzyszyły zmiany systemów podatkowych (opodatkowanie pracy), rynku pracy, oczekiwań konsumpcyjnych, które skutkowały brakiem poczucia bezpieczeństwa, niestabilnością ekonomiczną pomimo ciężkiej pracy, brakiem bliskich i głębokich relacji. Czynników prowadzących do zaburzenia ról społecznych z racji znacznie większej złożoności dostępnych zachowań i interakcji wśród ludzi jest bez porównania więcej niż w przypadku myszy. Nie bez wpływu pozostaje przypuszczalnie również stłoczenie dużych społeczności na małej przestrzeni. Tradycyjnie dominującym wzorcem interakcji między członkami społeczności były relacje ja - przyjaciel oraz ja - obcy, ja - wróg z członkami innych wspólnot. Dzisiaj mamy do czynienia z występowaniem relacji ja - obcy wewnątrz własnej społeczności. Według Ruth Benedict, wśród pierwotnych ludzi dominowała postawa skrajnej ksenofobii i prowincjonalizmu. Na porządku dziennym było nieuznawanie za takich samych ludzi osobników spoza własnego plemienia ${ }^{45}$. Dzisiaj wyróżniamy spośród tłumu wyłącznie członków własnej rodziny, znajomych i najbliższych sąsiadów, pozostałych nie zaszczycając nawet spojrzeniem, nie mówiąc o uśmiechu. Tworzymy bardzo małe plemiona, do których nie zaliczamy nawet mieszkańców własnego osiedla. Życie w stłoczonych miastach jest źródłem niebywałego stresu, związanego z rywalizacją i pośpiechem. Połączone z zawodowym dążeniem do sukcesu i rozwoju kariery sytuuje nas znowu w świecie symboliki świata gryzoni: nie przypadkiem takie postawy zwykliśmy nazywać wyścigiem szczurów.

Stres życiowy, wynikający z nieustającego poczucia niepewności, powstrzymuje nas przed podjęciem decyzji o posiadaniu potomstwa. Wydaje nam się to przedsięwzięciem tak długoterminowym i wymagającym, że nie jesteśmy w stanie podjąć tej decyzji w sposób przemyślany, w pełni odpowiedzialny i racjonalny. Dlatego znacznie większą dzietnością pochwalić się mogą środowiska defaworyzowane, wyłączone z rywalizacji wyścigu szczurów.

Reakcją przystosowawczą na nadmiar stresu jest agresja, bardzo często okazywana $\mathrm{w}$ formie autoagresji: uzależnień, chorób psychosomatycznych i psychicznych, wycofywania się z relacji społecznych, prób samobójczych. Poziom stresu uzależniony jest od pozycji zajmowanej w hierarchii społecznej, ,jednak w czasach rozchwianych hierarchii nawet u samców najwyższych rangą poziom stresu gwałtownie się podnosi. Zagrożenie własnej pozycji może być potężnym czynnikiem stresującym"46. Poziom stresu i poczucie zagrożenia

45 R. Benedict, Wzory kultury, Warszawa 2008, s. 70.

46 C. Wills, Dzieci Prometeusza. Teraźniejszość i przyszłość naszego gatunku, Warszawa 2002, s. 132-133. 
mogłaby zminimalizować przynależność do silnie integrującej wspólnoty, która oferowałaby wzmocnienie poczucia bezpieczeństwa oferowanego przez partnera i przez państwo (system zabezpieczeń socjalnych, opieki zdrowotnej, świadczeń prorodzinnych, polityki mieszkaniowej). Pokładanie nadziei wyłącznie w tym ostatnim doprowadzi do nakładania się dwóch przeciwstawnych wzajemnie kierunków oddziaływania inżynierii społecznej. Jeden nakierowany będzie na stymulowanie rynku pracy i ekonomicznej aktywności jednostek, a drugi na zwiększanie dzietności wbrew emancypacyjnej logice pierwszego.

Celem niniejszego artykułu nie było na szczęście projektowanie gotowych recept i rozwiązań de lege ferenda. Pragnąłem jedynie zwrócić uwagę na głębokie, kulturowe źródła kryzysu demograficznego, przed jakim stoi Zachód. Wizja człowieka i hierarchia wartości sprzyja konsumpcjonizmowi i zawodowej samorealizacji, wpływając na role społeczne, jakie przyjmują i realizują jednostki. Dalekosiężne konsekwencje takiego stanu rzeczy świetnie ukazują dzieła kultury: powieść Cząstki elementarne Michela Houellebecqa czy film Her w reżyserii Spike’a Jonze’a. Społeczeństwo, które stawia swoim członkom za cel uczestniczenie w zawodowym i konsumpcyjnym wyścigu szczurów, będzie skazane na samotność, wynikającą ze skrócenia i spłycenia relacji, instrumentalnie podejmowanych kontaktów. Stres, który generuje współczesny świat powoduje wycofywanie się ze społecznych interakcji, które niosą znaczące ryzyko porażki, negatywnej oceny, społecznego odrzucenia. Żyjemy za to w bezpiecznym świecie, w którym zminimalizowaliśmy skutki naturalnych katastrof, wojen, chorób epidemicznych. Obawiam się, że nawet gdyby zmienił się otaczający nas świat (przypadek myszy z eksperymentu Calhouna przeniesionych do innej populacji), kultura, która nas ukształtowała, nie pozwoliłaby nam na powrót do reprodukcji rozrzutnej. Wygląda na to, że tak jak starożytni Rzymianie trafiliśmy w ślepą uliczkę rozwoju i dokumentować możemy już tylko nasz własny, nieuchronny upadek, który polegał będzie na przechodzeniu w inną, całkiem odmienną od chrześcijańskiej, kulturę. Jej kształt będzie kontynuacją oświeceniowych wzorców antropologicznych tylko pod warunkiem opanowania przez technologię sztucznych sposobów rozmnażania, obok zapłodnienia pozaustrojowego, również inkubacji zarodka poza organizmem matki. W przeciwnym razie wydaje się, że sukces odniosą w Europie witalne wzorce cywilizacji islamu, będące podstawą do reprodukcji rozrzutnej. 


\section{Bibliografia}

Baader R., Śmiercionośne myśli. Dlaczego intelektualiści niszczą nasz świat, Wrocław 2009.

Becker C., Państwo Boże osiemnastowiecznych filozofów, Poznań 1995.

Benedict R., Wzory kultury, Warszawa 2008.

Bierdiajew N., Nowe Średniowiecze. Los człowieka we współczesnym świecie, Warszawa 2003.

Brumlik M., Gnostycy. Marzenie o samozbawieniu człowieka, Gdynia 1999.

Calhoun J., Death Squared: The Explosive Growth and Demise of a Mouse Population, http://www.ncbi.nlm.nih.gov/pmc/articles/PMC1644264/pdf/procrsmed00338-0007.pdf [dostęp: 26.04.2016].

Delsol C., Esej o człowieku późnej nowoczesności, Kraków 2003.

Giddens A., Konsekwencje nowoczesności, Kraków 2008.

Hazard P., Kryzys świadomości europejskiej 1680-1715, Warszawa 1974.

Himmelfarb G., Jeden naród, dwie kultury, Warszawa 2007.

Kant I., Co to jest Oświecenie, [w:] Z. Libera, Oświecenie, Warszawa 1974, s. 228-232. La Mettrie J., Człowiek-Maszyna, Warszawa 2003.

Mannheim K., Człowiek i społeczeństwo w dobie przebudowy, Warszawa 1974.

Maritain J., Trzej reformatorzy, Warszawa-Ząbki 2005.

Okólski M., Cywilizacje przypływu, cywilizacja odpływu demograficznego, [w:] Wiek wielkich przemian, M. Dobroczyński, A. Jasińska (red.), Warszawa-Toruń 2001, s. 11-30.

Picht G., Odwaga utopii, Warszawa 1981.

Polit K., Kryzys cywilizacji Zachodu w myśli José Ortegi y Gasseta, Lublin 2005.

Popper K., Nędza historycyzmu, Warszawa 1999.

Popper K., W poszukiwaniu lepszego świata. Wykłady i rozprawy z trzydziestu lat, Warszawa 1997.

Rousseau J.-J., Trzy rozprawy z filozofii społecznej, Warszawa 1956.

Rousseau J.-J., Umowa społeczna, czyli zasady prawa politycznego, Poznań 1920.

Schumpeter J.A., Kapitalizm, socjalizm i demokracja, Warszawa 1995.

Sepkowski A., Źródła populizmu w wyobrażeniach zbiorowych, [w:] Populizm na przełomie XX i XXI wieku. Panaceum czy pułapka dla współczesnych społeczeństw?, M. Marczewska-Rytko (red.), Toruń 2006, s. 95-100.

Szpotański Z., O wolności myślenia, Kraków 1986.

Taylor Ch., Etyka autentyczności, Kraków 2002.

Thurow L., Przyszłość kapitalizmu. Jak dzisiejsze siły ekonomiczne kształtują świat jutra, Wrocław 1999.

Wills C., Dzieci Prometeusza. Teraźniejszość i przyszłość naszego gatunku, Warszawa 2002. 
Dlaczego Zachód wymiera? Oświeceniowe źródła trendów antypopulacyjnych...

\begin{abstract}
The western societies are shrinking and getting older. These demographical processes have roots in civilizational solutions explored and imposed by the revolutionaries of Enlightenment. The cultural patterns created by the $18^{\text {th }}$ century philosophers are still and continuously actual. The set of modern and postmodern ideas including consumerism, self-realization and salvation during mortal life are the core reasons of demographical problems of western societies. People aren't eager to have families and children. They perceive the traditional way of life as a personal sacrifice. They feel a strong need to devote themselves to their own desires and joys. People live their lives as they were to be the last generation of their nations and seem not to be worried or even concerned by that fact.
\end{abstract}

Keywords: consumerism, self-realization, demography, crisis of the West, civilization, enlightenment, anthropology 